\title{
STRATEGY TO REDUCE STUNTING CHILDREN THROUGH EXPLORATION OF MOTHER'S EXPERIENCE
}

\author{
Nuning Dwi Merina ${ }^{1)}$, Tantut Susanto ${ }^{2)}$, Eka Afdi Septiyono ${ }^{3)}$ \\ 1,3 Department of Pediactric Nursing, Faculty of Nursing, Jember University, Jember, Indonesia \\ 2 Department of Community, Family, and Geriatric Nursing, Faculty of Nursing, Jember University, Jember, Indonesia \\ email: nuning.dwi@unej.ac.id
}

\begin{abstract}
Abstrak
Balita yang mengalami stunting memiliki tinggi badan yang lebih pendek daripada tinggi badan usia standar hal ini dikarenakan kurangnya asupan gizi dalam waktu yang lama. Perhatian seorang ibu terhadap gizi anaknya sangat penting untuk mengatasi stunting. Penelitian ini bertujuan untuk memberikan gambaran tentang pengasuhan keluarga pada anak yang mengalami stunting. Metode penelitian yang digunakan adalah kualitatif. Metode penelitian yang digunakan adalah wawancara secara mendalam dan melakukan observasi partisipan. Sampel penelitian adalah ibu yang memiliki bayi usia 12-59 bulan. Analisa data dengan mengidentifikasi tema dan topik dari wawancara. Pengelaman ibu dalam mengasih balita dilihat dari lima hal, 1) Tugas keluarga, 2) Lingkungan fisik dan sosial, 3) Komunikasi, 4) Ekonomi dan 5) Stres dan koping. Tenaga kesehatan dapat menggunakan hasil penelitian ini untuk membantu dan membimbing ibu dalam mengasuh anak yang sesuai dengan usia anak untuk mendukung pertumbuhan dan perkembangan anak secara optimal.
\end{abstract}

Kata kunci: pengasuhan, stunting

\begin{abstract}
Stunting on toddler has a shorter height than the standard age due to a lack of nutritional intake in a long time. The mother's attention to the nutrition of her child is needed in overcoming of stunting problem. This study aims to provide an overview of family care for stunting children. The research method was qualitative research. In-depth interviews and participant observation were used as collecting data. The subjects in this study were mothers who had children aged 12-59 months. Data were analyzed by identifying themes and topics from the interviews. Mother's experience in caring for children under five is seen from five issues, 1) Family tasks, 2) Physical and social environment, 3) Communication, 4) Economy, and 5) Stress and coping. Health workers can use this result research to assist and guide mothers in parenting based on their children's age to support growth and development optimally.
\end{abstract}

Keywords: parenting, stunting

\section{INTRODUCTION}

Stunting is a condition where a toddler has a length or height that is less than the standard age due to lack of nutritional intake in a long time (Kemenkes RI, 2018). The incidence of short toddlers or stunting in the world in 2017 was 150.8 million $(22.2 \%)$, with more than half of stunting toddlers coming from Asia (55\%) while more than a third (39\%) lived in Africa. Indonesia is among the third countries with the highest prevalence of stunting in the Southeast Asian region (Kemenkes RI, 2018). The prevalence of toddlers is very short, and the shortage of 0-59 months in Indonesia in 2017 is $9.8 \%$ and $19.8 \%$. This condition increased from the previous year, namely the prevalence of very short toddlers at $8.5 \%$ and short toddlers at 19\% (Kemenkes RI, 2018). East Java Province itself occupies the 27th position of stunting in 2018 with a very short incidence of under-fives $12.92 \%$ and short infants 19.89\% (Kemenkes RI, 2018). National Nutrition Status Monitoring data for 2016 states that in East Java, the stunting rate exceeds $40 \%$, which is in Sampang Regency, while Jember Regency itself has a stunting incidence of $39.2 \%$. In 2017 the first highest number of stunting under five cases occurred in the Jelbuk Health Center $(39.30 \%)$; the second rank was in the Arjasa Health Center $(38.78 \%)$ and third in the Sumberjambe Health Center (38.14\%) (Maulidah, 2018). 
One of the direct causes of stunting is intake. Low nutrient intake is influenced by parenting, one of which is improper feeding behavior (Margawati and Astuti, 2018). Parenting care for infants who are not creative and varied are important things that mothers need to pay attention to so that their child's nutritional needs are met (Loya and Nuryanto, 2017). Another factor that is also a direct cause of stunting nutrition problems is an infectious disease (Triana and Haniyah, 2020). Intake and infectious diseases are two things that are related to each other that need special attention so that no other nutritional problems occur (Almatsier, 2013). The indirect factors that can influence the occurrence of stunting are socioeconomic conditions, knowledge, education, food availability, health services, and political turmoil (Fikawati et al., 2019). These things are not a direct cause, but if an imbalance occurs, then it has the potential to be a problem that threatens the fulfillment of optimal nutritional needs in infants (Stewart et al., 2013).

Some efforts needed to improve better family parenting to support the development and growth of children (Moira et al., 2018). The intervention that can be done in an attempt to prevent stunting is to increase family knowledge so that it can improve feeding behavior in children (Castro et al., 2016). Increased knowledge to change feeding behavior in children, by nutrition counseling (Margawati and Astuti, 2018). The nurse as a counselor can help families to accompany or guide the family in creating appropriate parenting for the age of the child to support the child's growth and development optimally (Adams, T and A, 2017). This study aims to provide an overview of family parenting in children who has stunting risk.

\section{METHOD}

The research method is qualitative research. In-depth interviews and participant observation did data collection. This method was chosen to get indepth information about family parenting among children who are at risk of causing stunting. It is hoped that in the process of collecting data, it can also find new findings related to it because, in qualitative methods, researchers can develop questions raised to subjects and informants research. This research was conducted in Kemuning Village, Arjasa Subdistrict, Jember Regency, in August-September 2019. The topics in this study were mothers who had children aged 1259 months as many as ten mothers. The instrument in this study was an interview guide containing questions about family work, physical and social environment, family structure, family economic function, and family stress and coping. Record as a medium for collecting documentary data. Data analysis conducted was a qualitative analysis which was presented based on the data collected, after that the researcher determined the topics and themes from the participants' interview results. Qualitative data is processed according to the variables contained in the study with the induction method, which is drawing conclusions from specific cases to general matters and presented in the form of detailed images.

\section{RESULT AND DISCUSSION}

Participants in this study were ten mothers living in Kemuning Village, Arjasa District, Jember Regency. In this study, researchers identified the average age of participants in the age range of 20-30 years. Participant education is mostly high school graduate, but there are also those with elementary and bachelor education. The majority of participants do not work or are housewives, but some work as teachers and the private sector. The family type of all participants is a nuclear family. Most participants are Madurese, and one participant is Javanese. All participants are Muslim, and the average family income of participants is more than $1,000,000$ rupiah.

The researcher identified five themes as the results of this study; then, the themes were elaborated based on the specific objectives of the study. All themes have sub-themes with specific categories of meaning. The themes identified in the study include: 1) Family tasks, 2) Physical and social environment, 3) Communication, 4) Economy, and 5) Stress and coping.

1. The theme of family tasks in caring for children under five forms sub-themes to maintain closeness with children, time spent for children, how to improve children's growth and development, and how to help children to socialize with the environment. The things raised by the participants were as follows:

a. Maintain closeness with children

"... for example, when playing, it's accompanied ..." (R1)

"... when I get home from work, I bring cookies or toys ..." (R4)

"... when playing with my study accompanied ..." (R5)

"... yes, children are invited to play together. Just chat..." (R6) 
b. Time spent on children

"... yes, after returning home at noon, usually, right, I see the problem ..." (R2)

"... yes, about an hour ..." (R3)

"... only Monday to Friday ... yes, from that afternoon it was already ... at 5 o'clock after the afternoon shower ... after the Maghrib prayer continued until the evening ..." (R4)

c. How to improve the growth and development of children

"... invited to learn while invited to chat ... yes, invited to learn to be able to eat alone ..." (R1)

"I invite you to learn to read letters like a b c ... I invite you to sing songs together ... I teach reading prayers want to sleep with prayers want to eat ..." (R4)

"... yes, I invite you to write ... sometimes pictures of cars ..." (R10)

d. How to help children to socialize with the surrounding environment

"... I invite you to the neighbor's house when you visit ... neighbors have children of the same age, usually playing together ... playing outside with neighboring children of the same age, many friends ..." (R1)

"... rarely play outside ... often play with this next-door neighbor ..." (R4)

In interviews with family tasks, there are four sub-themes, namely maintaining closeness with children, time spent for children, efforts to improve child development and help children to socialize with the surrounding environment.

The results of interviews about the way mothers to maintain the closeness of children, namely mothers, have a way to maintain closeness with children by inviting children to play and learn. The child's relationship with parents is an emotional and cognitive resource for children. The mother and child relationship has been established since the child was born. The relationship between mother and child is very important because children depend on the mother's role in fulfilling nutritional and comfort needs. The way a mother in maintaining closeness with a child is to stimulate the child both in terms of visual auditory and tactile. The treatment of mothers in maintaining closeness with children is to bring children closer to introduce children to social and meet physiological and psychological needs (Nurhidayah, 2011).

The results of the interview regarding the time spent for a child that is the mother has a way to maintain closeness with the child that is the mother has certain hours to care for and look after her child. A toddler is a deciding factor for mothers to devote their time. Mothers who have toddlers have more time to pay more attention to growth and development. For working mothers, it will reduce their working time to care more for their children (Harahap, Lubis and Ardiani, 2015).

The results of interviews on how to improve the growth and development of children most of the mothers do things to stimulate children, such as inviting to play, learn, and pray. The role of mothers in character building in toddlers is very important, one of which teaches how to speak and teach children to socialize with the environment. The purpose of mothers in developing the growth and development of toddlers is by increasing children's language skills, teaching mathematical activities including counting activities, visual activities such as drawing, musical intelligence such as singing, kinesthetic intelligence such as dancing, friendship intelligence (socialization with the environment), information about knowing oneself such as know self-concept, and spiritual knowledge (Purnomo, 2013).

The results of interviews about the way mothers help children to socialize with the environment. Namely, most mothers invite their children to socialize with the environment. The environment has a role in the formation of social character in children. Mothers play a role in directing children in socializing with their surroundings. The social setting will teach children about environmental conditions, culture, language skills, and relationships (Purnomo, 2013):(Aktas et al., 2018).

2. Physical and family environment themes form sub-themes of how to maintain environmental health and family ways of looking after children's health. The things raised by the participants were as follows:

a. How to sustain environmental health

"... yes cleaned ... children should not play dirty things ..." (R1)

"... when my child plays, I clean ... my child tells me to play in the house ..." (R2)

b. How families take care of children's health "... must eat regularly ... sleep must be regular ..." (R1)

"... if the child does not feel well, go straight to the doctor ..." (R6)

"... if you get sick directly to the health center ... often massage twice a month ..." (R7)

"... if you play, you can't get dirty ... before eating, you have to wash your hands first ..." (R8)

"... I buy vitamins and give them to children ..." (R9) 
In the interview about the physical and social environment, there are three sub-themes, namely the way the mother in maintaining environmental health, the way the family in managing children's health, and the child's communication media. The conceptual framework by UNICEF in (Hartasari, Anggitya Titis and Muslifah Rachmawati, 2015) that affects children's health is maternal attention to children, stimulation/stimulus to children, hygiene practices, and care when a child is sick.

The results of interviews about how mothers take care of environmental health, that is, mothers clean their homes every day to keep the environment clean and comfortable to live in for their families, especially their children. Mothers who have paid attention to environmental health mean that mothers can fulfill one of the responsibilities in maintaining children's health.

The results of the interview on how mothers take care of their children's health, that is, mothers try to keep their children eating nutritious food, maintain children's hygiene, provide vitamins and also go to health services if the child is sick. The mother commits to look after her children's health. Most mothers always bring their children to the health center. Besides, mothers also have their ways to keep their children from getting sick. Children are easily or susceptible to diseases such as flu, diarrhea, coughing, fever, and infection, so the mother's readiness to take care of the child's health in terms of the child's environmental, physical, and psychological health (Hartasari, Anggitya Titis and Muslifah Rachmawati, 2015).

The results of interviews on child communication media, namely mothers, always communicate directly or converse with children. The role of the mother in the family includes the role of meeting basic needs, caring for and caring for the family, teaching and stimulating children. Children are the responsibility of parents to be raised and fulfilled their needs, such as nutrition, Communication, socialization with the environment, and learning. With excellent Communication, it will create a harmony of the family, and children become more confident in socializing with the environment (Azizah and Hartati, 2012). So that is the role of Communication in this study, mothers have tried to continue to maintain closeness and communication with children so that children can develop and are easier to socialize with their surroundings (Shire, Shih and Kasari, 2018).

3. Communication theme is only formed one subtheme, that is how to communicate with children.
The things raised by the participants were as follows:

a. How to communicate with children "... yes, directly talk to children ..." (R1)

"... if father works, the child usually looks around ... he must have called once or twice because the father, that Maghrib, would have returned ..."

4. Economic themes form a sub-theme of how families meet nutritional intake, family income, nutrition counseling, actions are taken when a child is sick and where for treatment. The things raised by the participants were as follows:

a. How families meet nutritional intake

"... yes, I was given healthy food ... I used to get breast milk too, but only until I was seven months old ... after that I finally drunk formula milk ..." (R1)

"... I usually give porridge ... normally I don't want rice ..." (R6)

b. Family income

"... yes, it's enough to eat kids every day, miss ..." (R1)

c. Counseling about nutrition

"... not yet ... have never been able to educate about nutrition ..." (R1)

d. Actions are taken by the family when the child is sick

"... taken to the health center ... if not yet healed also taken to the doctor's practice ..." (R1)

"... when I heat it I use red onions first ... if it's still not healed, I'll take it to the doctor" (R4)

e. A place for treatment

"... if you get sick, you will be taken to the health center directly ... usually I massage them too, once a month ..." (R2)

"... I massage it, sometimes twice a month ..." (R9)

In the interview about economic function, there are five sub-themes, namely how families meet their nutritional intake, family income, nutrition counseling, things families do when child is sick and where to seek treatment. The theory from UNICEF is the role of mothers in maintaining children's health, namely breastfeeding and other complementary foods, ways of feeding, and child health care.

The results of interviews on how families meet the child's nutritional intake of mothers trying to provide nutrition to children but still consider whether their children like or not to the foods. One of 
the women interviewed and said that the fulfillment of breast milk had reached more than six months but was not continued because the nipples were chafed and she was afraid of breastfeeding. In research, (Hartasari, Anggitya Titis and Muslifah Rachmawati, 2015) that the fulfillment of breast milk in infants can also be caused by inadequate culture or knowledge. Fulfillment of nutrition in children is also influenced by the child's favorite food so that parents sometimes obey the child's desire to eat even though the food is given less healthy foods such as snacks containing flavoring, coloring, and preservatives.

The results of interviews regarding family income, shows that mothers feel sufficient in meeting their daily needs. Economic status or the level of income earned by the family can have an impact on the way to serve food for families, especially toddlers (Rakhmawati and Panunggal, 2014). The better level of the family economy can affect the way mothers present food so that mothers can buy a variety of foods to be served to her family every day (Ningsih, Kristiawati and Krisnana, 2015).

The results of interviews about nutrition counseling, mothers said they never received advice about nutrition and nutrition for toddlers. Nutrition counseling is very important to do because it can increase the mother's knowledge so that the mother can do the best for the child, such as maintaining the child's health in physiological and psychological terms. Health education plays a role to improve parenting in children, and the mother has a concept of good health to avoid diseases that can attack her child (Tripitasari, 2009).

The results of interviews about things done when the child is sick, the mother will do something like compressing or smearing onions before going to health workers. If it is felt the child has not healed, the parents take their children to the health center or staff. Mother's childcare is influenced by the mother's knowledge, the distance of health facilities, and the mother's experience of caring for children (Azizah and Hartati, 2012). In this study, the mother was right in bringing her child to a health facility when sick. Health facilities in the village area of Kemuning Lor are midwives, and the location of the health center is not too far away so that mothers can reach health facilities more easily.

The results of interviews about where to go for treatment are mothers bringing their children to health services and also taking their children for traditional massages every two weeks to take care of children's health. Massage in children can increase serotonin secretion and cause changes in alpha, beta and theta waves in the brain thereby increasing sleep quality in toddlers (Mardiana and Martini, 2014).
5. The themes of Stress and coping form one subtheme that is the response made by the family. The things raised by the participants were as follows:

a. The answer made by the family "... I immediately brought it to the hospital ..." (R1)

"... taken directly to the midwife..." (R2)

"... I'll give you more milk consumption so I can get fat ..." (R4)

"... if I don't overthink... ignorant... what do people say ..." (R5)

"... I usually buy vitamins and take them to their children ..." (R7)

"... yes, I told the person that this is not malnutrition ... the child has been examined at the hospital, but yes, indeed his body is small ... I continue to give vitamins to his child ..." (R8)

In the interview about economic function, there is one sub-theme, namely the family's response when the child is said to be malnourished. In the results of discussions about family responses when children experience malnutrition, mothers have different reactions. According to Kubler Ross in (Faradina, 2016), there are five stages of a person's response, namely denial, anger, bargaining, depression, and acceptance. Mothers who are at the stage of rejection are mothers who state that their child is not malnourished, but after checking the health center, their children are in the red line. At the angry stage, the mother will express her feelings of anger as in the results of the interview that the mother said that the mother was "upset" when her child was supposed to be malnourished. Mothers at the bargaining stage will try to improve the nutritional status of their children, such as increasing milk consumption in children, buying children's vitamins, and being taken to a health facility (Lambert et al., 2004). While mothers at the acceptance stage, mothers will be ignorant and accept the condition of their children (Min et al., 2017).

\section{CONCLUSION}

Family experience in caring for children under five is seen from four themes, namely family tasks, physical and social environment, economic function, Stress, and family coping. The results of interviews from family assignments shows that mothers have a way to maintain closeness with children by inviting children to play and learn. mothers have certain hours to care for and look after their children, mothers stimulate children by 
inviting play, studying and praying, and mother asks her children to socialize with the environment.

The results of the interview from the theme of the physical and social environment, shows that, mother takes care the health of environment by cleaning house every day to keep the environment clean, keeping the child-eat nutritious food, maintains the child's hygiene, provide vitamins and also bring child to health services if the child is sick. The mother always communicates directly or converse with the child. The results of the interview with the theme of economic functions are mothers trying to provide nutrition for children but still consider whether their children like or not mothers feel sufficient in meeting their daily needs, mothers say they never get counseling about nutrition, mothers bring children to the health facility if the child is sick and doing massage once every 2 weeks. Interviews on the theme of a maternal family coping Stress have various statements such as the mother will be angry, take the child to the health facilities, and ignorant if the child is said to be malnourished.

\section{REFERENCE}

Adams, A. M. N., T, M. and A, H. (2017) 'Nurses' communication with families in the intensive care unit-a literature review', Nursing in critical care, 22(2), pp. 70-80.

Aktas, N. et al. (2018) 'Food and Nutrition Literacy Research: Content Analysis', Journal of Nutrition Education and Behavior, 50(7), p. S172.

Almatsier (2013) Prinsip Dasar Ilmu Gizi. Jakarta: PT Gramedia Pustaka.

Azizah, N. and Hartati, E. (2012) 'Pengalaman ibu pedagang dalam merawat anak', Jurnal Nursing Studies, 1(1), pp. 1-8.

Castro, K. et al. (2016) 'Feeding behavior and dietary intake male children and acolescents with autism spectrum disorder: A casecontrol study', International Journal of Developmental Neuroscience, 53(1), pp. 6874.

Faradina, N. (2016) 'Penerimaan diri pada orang tua yang memiliki anak berkebutuhan khusus', Psikoborneo, 4(1), pp. 18-23.

Fikawati, S. et al. (2019) 'Research Article Age of Milk Introduction is a Dominant Factor of Stunting Among Toddlers Aged 24 Months in Bogor District: A Cross-Sectional Study'.
Harahap, R., Lubis, Z. and Ardiani, F. (2015) 'Gambaran Perilaku Sadar Gizi Pada Keluarga Yang Memiliki Balita Gizi Kurang dan Gizi Buruk Yang Ada Di Wilayah Kerja Puskesmas Desa Lalang Tahun 2014', Gizi, Kesehatan Reproduksi dan Epidemologi, 1(4).

Hartasari, C., Anggitya Titis, P. and Muslifah Rachmawati, A. (2015) 'Pola Asuh Balita Ibu-ibu Kelompok Sasaran Pada Program Kegiatan Bina Keluarga Balita Usia 0-12 Bulan Dusun Gandekan Kartasura', Informasi, 45(1), pp. 1-14.

Kemenkes RI (2018) Situasi Balida Pendek (Stunting) di IndonesIa. Jakarta: Pusat Data Dan Informasi.

Lambert, J. et al. (2004) 'Dietary intake and nutritional status of children and adolescents in Europe', British Journal of Nutrition, 92(S2), pp. S147-S211. doi: 10.1079/BJN20041160.

Loya, R. R. P. and Nuryanto (2017) 'Pola Asuh Pemberian Makan pada Balita Stunting Usia 6-12 Bulan di Kabupaten Sumba Tengah Nusa Tenggara Timur', Journal of Nutrition College, 6(1), pp. 83-95.

Mardiana, L. and Martini, D. E. (2014) 'Pengaruh Pijat Bayi Terhadap Kualitas Tidur Bayi Usia 3-6 Bulan di Desa Munungrejo Kecamatan Ngimbang Kabupaten Lamongan', Surya, 2, pp. 10915.

Margawati, A. and Astuti, A. M. (2018) 'Pengetahuan ibu, pola makan dan status gizi pada anak stunting usia 1-5 tahun di Kelurahan Bangetayu , Kecamatan Genuk , Semarang', Jurnal Gizi Indonesia (The Indonesian Journal of NutritioN), 6(2), pp. 82-89.

Maulidah, W. B. (2018) Faktor yang Berhubungan dengan Kejadian Stunting Pada Balita di Desa Panduman Kecamatan Jelbuk Kabupaten Jember. Universitas Jember. Available at: https://repository.unej.ac.id/.

Min, J. et al. (2017) 'Maternal perseption of child overwight status and its association with weight-related parenting practices, their children's health behaviours and weight change in China', Public health nutrition, 20(12), pp. 2096-2103. 
Moira, M. et al. (2018) 'Exhausted Parent: sociodemographic, child-related, parentrelated, parenting and family-fuctioning correlates of parental burnout', Journa; of Child and Family Studies, 27(2), pp. 602614.

Ningsih, S., Kristiawati and Krisnana, I. (2015) 'Hubungan Perilaku Ibu dengan Status Gizi Kurang Anak Usia Toodler', Jurnal Pediomaternal, 3(1), pp. 58-65.

Nurhidayah, S. (2011) 'Kelekatan (Attachment) dan Pembentukan Karakter', Turats (Jurnal Pemikiran dan Peradaban Islam), 7(2), pp. 78-83.

Purnomo, H. (2013) 'Peran Orangtua Dalam Optimalisasi Tumbuh Kembang Anak Untuk Membangun Karakter Anak Usia Dini', Prosiding Seminar Nasional Parenting, pp. 34-47.

Rakhmawati, Z. N. and Panunggal, B. (2014) 'Hubungan Pengetahuan dan Sikap Ibu dengan Perilaku Pemberian Makanan Anak Usia 12-24 Bulan', Journal of Nutrition College, 3(1), pp. 43-50.
Shire, Y. S., Shih, W. and Kasari, C. (2018) 'Brief Report: Caregiver Strategy ImplementationAdvancing Spoken Communication in Children Who are Minimally Verbal', Journal of autism and developmental disorders, 48(4), pp. 1228-1234.

Stewart, P. C. et al. (2013) 'Contextualising complementary feeding in a broader framework for stunting prevention', Matern Child Nutrition, 2(2), pp. 27-45.

Triana, Y. N. and Haniyah, S. (2020) 'Relationship Between Characteristics of Children, Status of Infectious Disease, and Employment Status of Mothers with Stunting Children at Karanglewas Health Center', $1 s t$ International Conferenceon Community Health (ICCH 2019), 20, pp. 168-173.

Tripitasari, D. I. (2009) Konsep dan Praktik Ibu dalam PemberIan ASI dan MP-ASI serta Pemantauan Pertumbuhan Balita di Komunitas Adat Tertinggal (Studi Kualitatif pada Suku Anak dalam Sungai Teras Kabupaten Musi Rawas Sumatera Selatan). Universitas Diponegoro. 